\title{
PSYCHOLOGICAL ASPECTS OF SOCIAL CAPITAL UNDER GLOBALIZATION
}

\section{Smuk O. T.}

\section{INTRODUCTION}

Today's events show that the world is ready to create a cohesive global community. So far, however, it has been difficult to make predictions for the future and, therefore, one must realize that it is what one aims for, not vice versa. Mankind lives in another time, in a new dimension, under the conditions of information culture, world values and globalization processes. Globalization has not only opened new horizons for the development of society but also exacerbated previously unresolved social contradictions and brought new challenges to the world. W. Beck believes that the global community is transformed into a society of risk, which marks the beginning of a new era, which he calls "second modernity" . One can observe an increasing probability of risks associated with the unpredictable consequences of the introduction of new communication and bioengineering technologies, climate changes, chronic imbalances in labour markets, as well as the creation of an army of "superfluous people"2.

Now, it is quite natural to cultivate a person guided by purely economic considerations. Homo economicus completely reduces a person to the level of economic behaviour. It integrates them into financial systems, obliges them to obey the requirements of mass behaviour and, as a result, makes their unique personality superfluous and even harmful ${ }^{3}$.

The conflict of relations between a person and the social environment has caused a paradigmatic crisis. The modern world develops in the context of global changes. Besides, there is the instability of social relations built on the values which do not allow reconciling the interests of different groups of people and states. Both the globalization and unification of the world lead to unprecedented levelling and equalization of societies and people and create conditions for them to feel superfluous. Thus, people

\footnotetext{
${ }^{1}$ Бек У. Общество риска: На пути к другому модерну. М.: Прогресс-Традиция, 2000. 383 с.

${ }^{2}$ World Economic Forum. Global Risks 2013, Eighth Edition. P. 10. URL: http://www.weforum.org/ issues/global-risks.

${ }^{3}$ Серый А. В., Яницкий М. С. Ценностно-смысловая сфера личности. Учебное пособие. Кемерово: Кемеровский государственный университет, 1999. С. 230.
} 
become hostile to sociality, and the very of personality is "nullified". The personality of globalization is useless since it undermines the artificially created global systems promoted by globalism due to its creativity and rejection of global simplification, averaging and equalization ${ }^{4}$.

The crisis of identity, as well as the loss of national cultural traditions, acts as the effect and one of the greatest dangers for a person included in the global market system. The lack of these factors leads to their marginalization, allows manipulating them and creating the illusion of complete self-realization. The global cultural crisis is associated with the spread of primitive standards of consumerism which distorts the worldview and values of the population. The current Western form of globalization causes the establishment of the mass depersonalized "culture", devoid of spiritual and moral guidelines and based on a single market-related criterion of profit. This mass pseudo-culture imposes the norms and stereotypes of a consumer society, the cult of force and cruelty, the violation of others' human rights, the desire to dominate at any cost $\mathrm{t}^{5}$.

The answer to today's challenges should be the restructuration of certain worldviews and the emergence of new socio-psychological levers that will balance and harmonize the interaction between a person and society, as well as build optimal forms of social relations as a relationship of permanent consent.

The globalization of economies and the corresponding problems have highlighted the need to change people's worldview and revise key areas in the development of society. They are as follows: a gradual shift from market to social orientations of the development; a shift from "an economic type of a person" aimed at maximizing income to a social type focused on the development of spiritual enrichment and self-development.

\section{A psychological resource of social capital and its axiological component}

The social capital theory originated in the 1960s after the recognition of works by American economists T. Schultz and G. Becker on the concept of human capital. It revealed the economic role of education and the relationship between investments in human capital and the increase in the level of labour productivity. French sociologist P. Bourdieu conducted a content analysis of social capital, defined it as the sum of resources and

\footnotetext{
${ }^{4}$ Крупнов Ю. Борьба за личность личность. URL: http://www. kroupnov.ru.

${ }^{5}$ Ritzer G. The McDonaldization of Society. An Investigation into the Changing Character of Contemporary Social Life. Thousand Oaks, CA: Sage, 1993.
} 
justified the possibility of realizing social capital by converting it into other forms of capital. American economist and sociologist J. Coleman considers social capital as a resource contributing to the development of the economy and improving society as a whole . $^{6}$

F. Fukuyama understands social capital as a set of informal rules and norms adopted by members of the group which allow them to interact with each other. Once they expect their colleagues to behave reliably and honestly, they trust each other. Trust, as the main component of social capital, allows a group or company to function more efficiently. Any society has a certain stock of social capital, and the real differences between societies are due to the so-called "radius of trust". Although social capital is created and maintained in interpersonal and intergroup relations, it should not be confused with cohesion and solidarity. The latter can be created both by a positive attitude towards the external social environment when members of other groups are attributed positive qualities (a large radius of trust, according to F. Fukuyama) and a negative one when external groups are perceived hostile (a large radius of distrust). In the second case, social ethics justifies immoral behaviour towards others for the good of one's own (double standards), and total social capital decreases ${ }^{7}$.

According to A. Zhuravlyov, A. Kupreichenko ${ }^{8}$ and T. Skrypkina ${ }^{9}$, the key category of social capital is trust. The researchers believe that it is a system-forming factor of social capital, whose psychological content is endowed with the characteristics inherent in the congruence of expectations of the actors in relations (predictability), social competency, as well as the identification of life values.

Lately, both economic, cultural and socio-psychological components reflecting the specifics of human relations under certain socio-economic conditions have been considered as important factors in the development of society. L. Pochebut ${ }^{10}$ presents arguments indicating the need to study the psychological content of social capital through a set of interpersonal relations, whose actualization is associated with the achievement of one's goals. In this case, interpersonal relations acquire an instrumental function. The concept of "social capital" is interpreted more broadly since there are different forms of it.

\footnotetext{
${ }^{6}$ http://www.dridu.dp.ua/vidavnictvo/2017/2017_04(35)/11.pdf.

${ }^{7}$ Фукуяма Ф. Конец истории и последний человек . М.: Ермак, 2004. 588 с.

8 Журавлев А.Л., Купрейченко А.Б. Нравственно-психологическая регуляция экономической активности. М., 2003. 436 с.

${ }^{9}$ Скрипкина Т.П. Психология доверия. М., 2000. 264 с.

${ }^{10}$ Почебут Л.Г. Психология социальных общностей. Толпа, социум, этнос. Изд-во СПбГУ, СПб., 2002. 176 c. URL: https://www.livelib.ru/author/238202-lyudmila-pochebu.
} 
A significant factor in the disclosure of psychological resource of social capital is an axiological sphere of a person (group), whose social experience is developed during social ontogenesis. The main values determining the leading (axiological) orientation of a person and revealing the system of their values and attitude towards society and themself is one of the most important elements of social capital. At the same time, researchers mostly attempt to conceptualize the concept of social capital through the category of relations. Although there are some specific approaches and research opportunities to reveal the psychological content of social capital, it is still difficult to implement it.

M. Shikhirev ${ }^{11}$ has significantly contributed to developing the issue of social capital and its psychological component. The scholar emphasizes that social capital is responsible for the quality of social relations. He claims that the key elements of the social network include actors in the interaction, relatively stable relations, subjective assessment of these relations, the adopted rules of the interaction.

A theoretical and empirical study on social capital by N. Lebedeva and $\mathrm{O}$. Tatarko proves that there is a socio-psychological resource of personality. It interprets it as "socio-psychological capital of a person"12. Yet, the researchers view socio-psychological capital as an integral sociopsychological quality based on the resource of a person's attitude towards society and their immediate environment. Its criteria include trust, subjective well-being and personal adaptability in society.

Thus, one can conclude that social capital can be accumulated during social interaction since social relations expand and the range of acquaintances useful to a person increases. In a certain accumulated state, these social relations create a network of the already established contacts which contribute to achieving the goals of a whole group of people. Due to integration, many social networks further become part of the social structure and affect the social life of the society. This sequence corresponds to three levels of understanding social capital, namely, micro, meso- and macro-levels. At the micro-level, social capital is seen as a set of a person's resources; at the meso-level - that of social groups; at the macro-level - that of society as a whole.

\footnotetext{
${ }^{11}$ Шихирев П.Н. Природа социального капитала: социальнопсихологический подход. Общественные науки и современность. 2003. № 2. С. 17-32.

12 Татарко А. Н. Индивидуальные ценности и социально-психологический капитал : кросскультурный анализ. Психология. Журн. Высш. шк. экономики. 2012. Т. 9, № 1. С. 71-88.
} 
A. Bahniuk introduces the term "social quantification" 13 He believes that this concept can help to logically justify the exchange of any form of capital between people in society. He considers social capital as the capital of human communication and relations in the society "through the exchange of quanta of truth, goodness, beauty, justice, law, faith, truth". As one can see, the author associates social capital exclusively with positive processes useful for society.

$\mathrm{V}$. Yelahin states that both an individual social entity and a group as a whole have a certain "radius of trust", i.e. those interactions covered by institutional non-formal adapted norms ${ }^{14}$.

S. Syvukha and O. Shuba study the issues and prospects of social capital development in Ukraine. Also, H. Andrushchenko and $\mathrm{T}$. Nedelcheva focus on the relations between trust and social capital. Interestingly, A. Bova claims about the declining trend in social capital in Ukraine ${ }^{15}$. He believes it is because of decreasing public confidence in public authorities. The scholar equates the concept of social capital to trust between different social strata. He sees the macro-level of social capital, i.e. trust, against the background of increasing activity of various social actors and organizations.

For many decades, psychology has been developing the category of relations in its specific way. However, it is important to note that other psychological schools were wary of attempts to create a human relations theory. Thus, this approach is unjustified since this theory has a strong humanistic origin. In the West, its founder is considered to be E. Mayo, although V. Bekhterev, A. Lazurskyi and V. Miasyshchev also indicated the need to develop such a theory in psychology.

Values serve as the main regulator of human behaviour and activity, thus determining the direction of this activity. Besides, they define the nature of social relations.

Thus, Ukrainian researchers understand the essence of social capital rather ambiguously. Their views can be classified based on the field of study on social capital: sociological economic, political, historical and psychological approaches. However, it is possible to highlight the common feature of all concepts of social capital. It is an intangible form of capital, which characterizes the level of interaction between social

\footnotetext{
${ }^{13}$ А. Багнюк. Соціальний капітал і квантифікація суспільних процесів: тлумачення і функції. Мультиверсум. Філософський альманах: Зб. наук. пр. К., 2008. Вип. 71. С. 14-40.

${ }^{14} \mathrm{http}: / /$ www.philosophy.univ.kiev.ua/uploads/editor/Files/Vydanna/Visnyk.

${ }^{15} \mathrm{http}: / /$ dspace.nbuv.gov.ua/bitstream/handle/123456789/38122/11-Chetverikova.pdf? sequence=1.
} 
actors based on values and communication, which, in turn, are based on trust and tolerance ${ }^{16}$.

Every historical epoch presupposes certain social relations, and, therefore, they are based on the realization of characteristic values. In traditional societies, such forms developed gradually in the course of long-term coordination of what was objectively significant and valuable for different groups of people under specific conditions of place and time. This research claims that only studying the nature of a person's values and their origin, one can identify axiological principles of an optimal form of social relations, which reconciles the interests of people, different social groups, states and all mankind.

The configuration of dominant values is one of the important elements of a single semantic field of both social community and its social capital. V. Chepak and E. Hunin ${ }^{17}$ consider social capital as a multifunctional phenomenon. They believe that social capital can manifest itself simultaneously in several forms, namely, in the form of individual interest; in the form of interest of a particular group, team, community; in the form of public interest. Thus, social capital can exist in many dimensions, although it is based on the person and their attitude towards society.

The social experience incorporated in personal experience integrates with a person's individual experiences and the experience of individual existence. This process occurs through the emergence of personal values, which are considered as the structures of individual consciousness. Thus, social and cultural values, first of all, arise as personal values. They act as cognitive forms which can capture a person's striving for something significant and corresponding to their marginal (at the time of their emergence) socio-cultural and natural opportunities.

The analysis of manifestations of the projective function in the values system shows that social relations are determined by all personal values which are a special form of the existence of such a system. On the one hand, it is unique. On the other hand, it reflects what is objectively common to different people and social groups. Axiological principles of social relations reflect people's desire to reproduce those qualities of relations which help to successfully implement some social function and are defined as significant concerning it. Still, not all significant normative qualities of social relations are enshrined in their axiological principles,

${ }^{16}$ Социальный капитал личности: монография / Л. Г. Почебут, А. Свенцицкий, Л. В. Марарица, Т. В. Казанцева. М.: НИЦ ИНФРА-М, 2016. 250 с.

${ }^{17}$ Е. Гугнін, В. Чепак. Феномен соціального капіталу. Соціологія: теорія, методи, маркетинг. 2001. № I. C. 49-57. 
only those which should be present in all variable ways of their organization. Therefore, values are always a reflection of variable qualities and a form of expressing conceptual principles of these relations.

The determination of axiological principles of some social relations lies in identifying what is objectively significant for the proper performance of the main social function in such relations and establishing the significance of what is defined as objectively significant. One should start searching for a universally significant option from the identification of what is essential for a person's relationship with reality. In essence, the significant is manifested through studying the main qualities of a person and identifying the objectively necessary for them, which helps to fully manifest these qualities.

If one proceeds from the fact that axiological principles of social relations reconcile the significant for states, society, other people and a person as the actor in social relations, one should identify culturalhistorical and individual aspects of these relations. These levels of the significant are reflected in the hierarchical structure of axiological principles of social relations.

Now, there is the growing number of studies and publications on the issues of globalization, related global challenges and the evolution of axiological principles of societies. S. Schwartz ${ }^{18}$ was first who laid the foundation of this approach. The researcher attempted to identify universal values inherent in all world cultures, namely, charity, adherence to rules and norms, hedonism, power, security, self-government, encouragement, tradition and universalism. However, this definition never became generally accepted. The global network called "Global Values"19, one of the authoritative sources in this context, defines such ten components of the global values system as unity, community, life, freedom, relationships, sustainability, creativity, empowerment, choice, the integrity of being. Thus, it emphasizes the debatable nature of its many aspects.

A system-forming element of this system are values reflecting the objectively significant for a person's existence. They, first of all, determine the nature of an optimal form of all human relations with reality, including social relations. The determination of the significant for human existence in social relations should be based on the identification and study of a person's ancestral qualities, needs and conditions of existence, as well as on the establishment of relations between them.

\footnotetext{
${ }^{18} \mathrm{https}$ //zg-brand.ru/marketingovye-issledovaniya/cennostnyj_oprosnik_sh_shvarca.

${ }^{19} \mathrm{https}$ ://www.corteidh.or.cr/tablas/27917.pdfhttp://www.irbis-nbuv.gov.ua/cgi-.
} 
In Ukraine, the most notable fundamental study in this area, although not without some contradictions between its authors, is a collective monograph by $\mathrm{Yu}$. Pakhomov and $\mathrm{Yu}$. Pavlenko ${ }^{20}$. The researchers employ a broader approach to interpreting axiological principles. It lies in an in-depth analysis of the evolution of spiritual values and general worldview underlying the modern development in the context of globalization. However, most studies on relations between global processes and axiological values are not much focused on the global challenges organically linked to the global social transit.

As of today, Ukraine has failed to adequately fit into the global system and has not created adequate mechanisms ensuring its development in the context of powerful global challenges. The country's axiological values have been significantly distorted by global processes. However, some potentially positive trends in global processes (environmental orientation, corporate social responsibility, standards for financial and tax spheres) still do not have a proper impact on Ukraine. Both of these circumstances significantly complicate the country's development and modernization and urge significant changes in the future development policy.

One can achieve the highest efficiency of using social capital in the context of consolidating social and individual goals and, ideally, approaching the social optimum. It means achieving common goals through individual ones and coordinating economic processes with human development.

Thus, one can conclude that social capital can be accumulated during social interaction due to the expansion of social relations and the increasing range of useful acquaintances. In a certain accumulated state, these social relations create a network of established contacts which contribute to achieving the goals of some groups of people. Subsequently, many social networks integrate, become part of the social structure and affect the social life of the society. This sequence corresponds to the following three levels of social capital, namely, micro-, meso- and macro-levels. At the microlevel, social capital is seen as a set of a person's resources; at the mesolevel - that of social groups; at the macro-level - that of society as a whole. A social network of relations becomes an element of social capital when these relations are useful and help a person to achieve some goals. The social structure to which a person belongs potentially contains certain advantages. However, when these advantages are used inappropriately, they do not create social capital.

\footnotetext{
${ }^{20} \mathrm{http} / / /$ www.irbisbin/irbis64r_81/cgiirbis_64.exe?C21COM=2\&I21DBN=VFEIR\&P21DBN=VFEIR\& $\mathrm{Z} 21 \mathrm{ID}=\& I m a g e \_f i l e \_n a m e=D O C \% 2 \overline{\mathrm{F}}$ EIR0021604.PDF\&IMAGE_FILE_DOWNLOAD $=1$.
} 


\section{The role of social capital in the system of social relations on the example of Transcarpathian region}

Ukraine ranks $88^{\text {th }}$ out of 189 countries in the human development index ranking. The country is showing progress in human development, despite the armed conflict in Donbas and the associated economic shocks, as stated in the UN Development Program in Ukraine ${ }^{21}$.

I. The resource component is human capital. The resource component of accumulating social capital is a kind of "a basic element" for its creation. People are a key goal and the most important determinant and factor in social and economic development. Every year, the UN Development Program calculates the Human Development Index for the countries of the world. Ukraine's human development index is equal to 0.63 in 2020, being below the average level in Europe and Central Asia. Ukrainian youth do not have the opportunity to become productive adults. A new-born child can only achieve $63 \%$ of the productivity of an adult with a sufficient level of education. Therefore, it is essential to invest in education, health care and social protection to solve this particular issue ${ }^{22}$.

The regional context shows that there are certain disparities with this indicator. Indeed, the highest value of the Human Development Index is characteristic of Kharkiv, Chernivtsi, Lviv and Zakarpattia regions. Still, this value is below average and low in most regions of Ukraine ${ }^{23}$.

This research analyzes the important influence of social capital on the development of a strong civil society and, consequently, identifies the role of social capital in the system of social relations in Transcarpathian region.

The answers of the residents of Transcarpathian region regarding the assessment of trust in people from the proposed groups were divided as follows (see Diagram 1).

Diagram 1 shows that, apart from trusting relationships with families (68.1\% of respondents rated family relationships as trusting), neighbours $(20 \%)$ and acquaintances $(18.2 \%)$, the residents of Transcarpathian region demonstrate a fairly high level of trust in people of other nationalities and religions $(13.7 \%$ and $19.4 \%$ respectively). It means that they tend to be respectful and tolerant. Moreover, a large proportion of locals feel "indifferent" to religion and nationality.

${ }^{21} \mathrm{https} / / /$ zik.ua/blogs/buty_sered_pershykh_981037.

https://mind.ua/news/20215947-indeks-lyudskogo-rozvitku-v-ukrayini-za-ostanni-10-rokiv-nepokrashchivsya.

${ }^{23} \mathrm{http} / / /$ www.ukrstat.gov.ua/druk/publicat/kat_u/2018/zb/09/zb_rlr2017_pdf.pdf. 
Diagram 1

\section{A measure of trust in people from the proposed group (\%)}

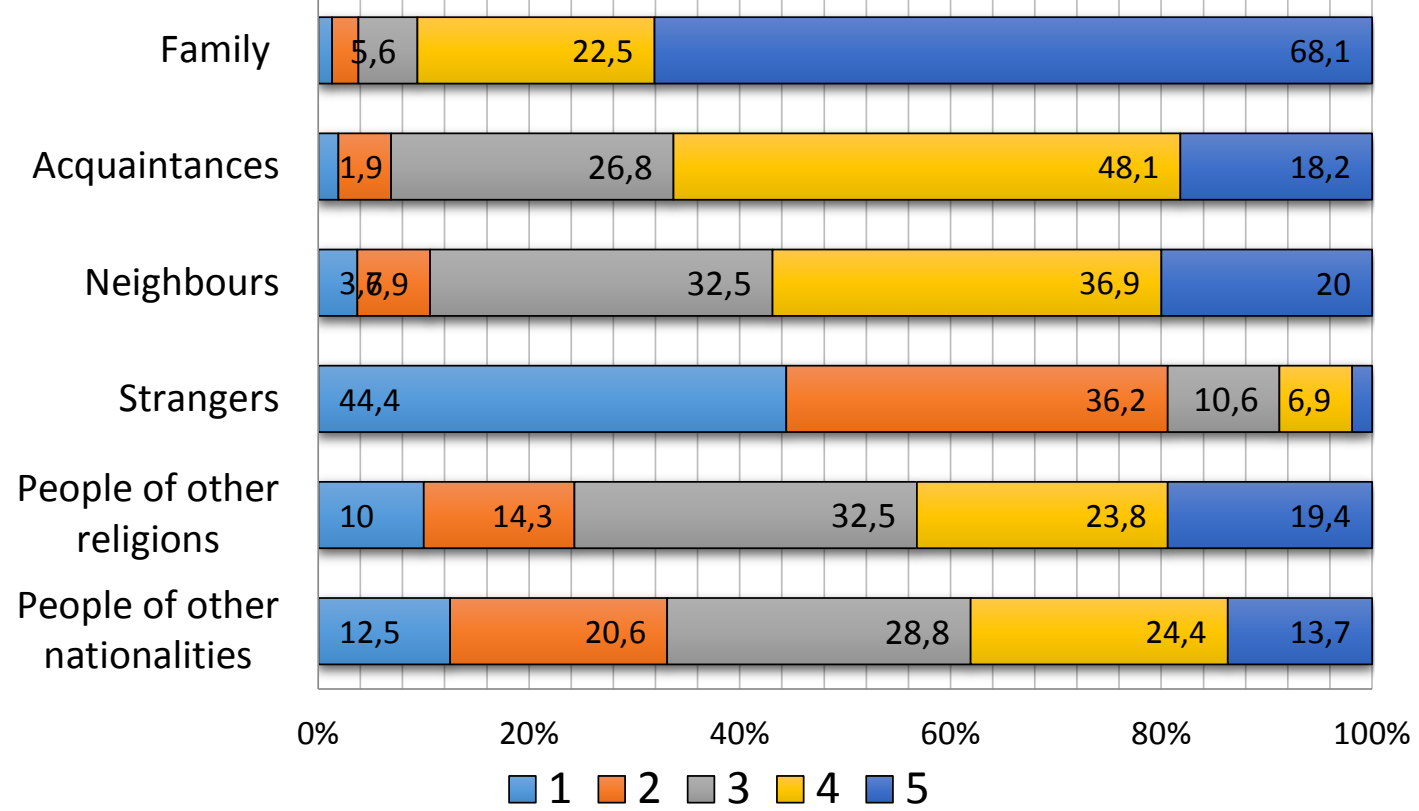

Diagram 2

"Do you provide special assistance to at least one patient, a person with special needs or an elderly person who lives/does not live with you?"

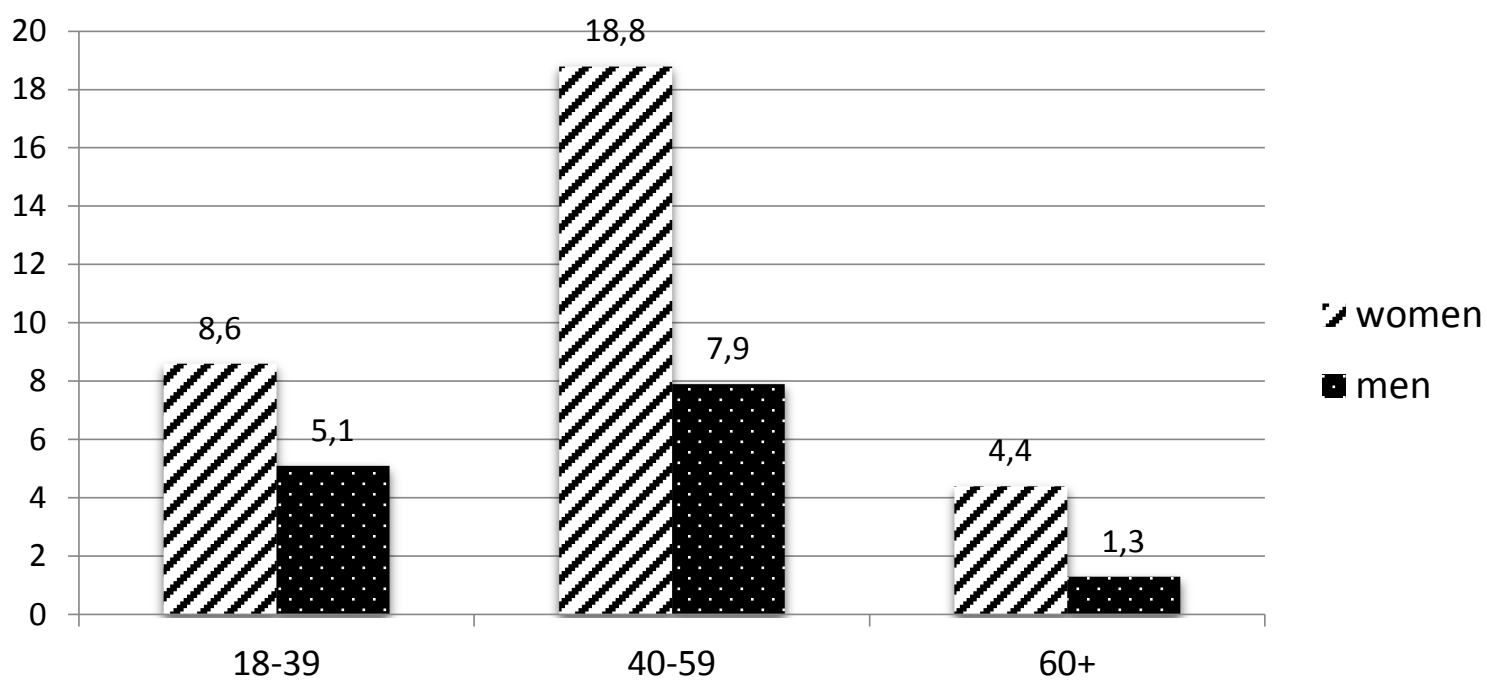

Mostly women answered "yes" to the question "Do you provide special assistance to at least one patient, a person with special needs or an elderly person who lives/does not live with you?" (see Diagram 2). The figure of $46.1 \%$ implies high indicators of assisting a person in need. 
Over the last month, $34.8 \%$ of the respondents have helped a stranger and $17.3 \%$ of them have donated to charity. Interestingly, $78 \%$ of them are city residents. It proves that in cities, there is a greater need to help financially and share other valuable resources, such as time, attention, support.

Healthy personal relationships can be a protective factor against stress and other health issues. The percentage of people who say they feel lonely is often or always $6.6 \%$. The analysis of respondents' answers to questions related to the indicators of interpersonal relationships shows that $74.2 \%$ of respondents have at least one close friend they can rely on and $57.6 \%$ of them meet with friends, relatives and colleagues at least 1 once a week.

At the same time, $28.3 \%$ of respondents claim that when they meet their neighbour on the street, they stop for a chat. It indicates positive social capital since capital is based on relationships, a system of relations with each other.

Approximately $61 \%$ of respondents have used the Internet to communicate in the last month. Although the studies on the links between social networks and social capital are still in their early stages, they demonstrate that social networks can help strengthen social capital by helping people build relationships and promote integration into communities. Therefore, a high level of using social networks for communication can be considered as positive social capital.

Most residents of Transcarpathian region believe it necessary to cultivate honesty and tolerance in children in the first place. If one educates the next generations on such principles, one can expect a great future for the society.

As far as the indicators of civic activity are concerned, the percentage of respondents believing in fair elections in the region is very low $(9.4 \%)$. This is especially the case with the residents of Mukachevo. As it turned out, about one-fourth of respondents $(24.3 \%)$ are interested in the policy of the region, of which $79 \%$ are people over 40 years old. It means that the younger generation is almost not interested in the political sphere of society. Only $7.2 \%$ of respondents believe that they can influence the decisions of local/regional authorities. It is an extremely low level of trust in the government. However, 19\% of respondents indicated that they were involved in the activities of nongovernmental associations or organizations. Besides, $26 \%$ of them have been involved in some volunteer work over the last month. In this regard, the residents of Transcarpathian region are ready to invest their 
resources in the development of society. The only issue is that the current government are not on the best of terms with them.

Thus, the obtained results indicate a fairly high level of social capital in Transcarpathian region, which is based mainly on trust in each other. One of the negative aspects of social capital is such phenomena as nepotism and corruption, which arise from the devaluation of other people's social relationships. The residents' willingness to help those in need, not only financially but also with other resources, can be considered as the positive effect of social capital in Transcarpathian region.

II. The environment-related component of social capital development covers the socio-psychological and institutional environment. The sociopsychological environment is manifested in the form of social norms and a level of trust within society. The cohesion of society through common goals, values, norms and mutual trust determines a level of institutional receptivity, as well as the effectiveness of policies aimed at socioeconomic development.

As noted by the Legatum Institute (the UK), Ukrainians are quite isolated since they demonstrate a low level of involvement in public life outside the family and an average level of social trust.

Table 1 presents the indicator values of the manifestations of social norms in Ukrainian society. Analyzing these indicators, one can conclude that family values are strong in Ukraine since the number of married people exceeds the world average, and a large percentage of those who can rely on relatives and friends is equal to $89.6 \%$.

Ukraine shows a high percentage of those involved in volunteer work $(26.3 \%)$. According to this indicator, Ukraine is among the top twenty countries in the world. This is evidence of Ukrainians' readiness to make personal investments in the development of society, realizing their abilities in the form of free services. On the other hand, financial investments in the development of society in the form of charity are insignificant, that is only $9.0 \%$. This figure can be explained by low standards of living and low social responsibility of business.

Also, the percentage of Ukrainians attending church is quite low $(28.6 \%)$. Instead, religiosity is an important factor in civil society with a high level of social capital accumulation since it affects all spheres of public life. In particular, a high level of bribery, inefficient public administration and, as a result, inefficient use of social capital is partly a consequence of low religiosity in society and ineffective internal moral laws, which leads to ineffective legal norms of society. 
Trust within society is an important component of the sociopsychological environment. The level of trust is influenced by social norms, on the one hand, and by the institutional environment, in particular individual perception of state regulation effectiveness, on the other hand.

Table 1

Some values of manifestations of social norms in Ukrainian society in 2019 (\% of the respondents who answered "yes")

\begin{tabular}{|l|c|c|}
\hline \multicolumn{1}{|c|}{$\begin{array}{c}\text { Values of manifestations of social norms } \\
\text { in Ukrainian society }\end{array}$} & Ukraine & $\begin{array}{c}\text { In the world } \\
\text { (on the average) }\end{array}$ \\
\hline Donation of money to charity over the last month & 9.0 & 28.9 \\
\hline Assistance to a stranger over the last month & 35.4 & 48.9 \\
\hline Marriage & 55.6 & 50.4 \\
\hline Church attendance & 28.6 & 49.2 \\
\hline Reliance on relatives and friends & 89.6 & 79.9 \\
\hline Trust in other people & 30.7 & 24.2 \\
\hline Involvement in volunteer work over the last month & 26.3 & 20.9 \\
\hline
\end{tabular}

The research by the Legatum Institute shows that inefficient public administration in Ukraine leads to a low level of public trust. Indeed, only $21.1 \%$ of Ukrainians trust the government, and $10.2 \%$ of them support the government's efforts to overcome poverty. The level of corruption in Ukraine exceeds the world average and is equal to $83.3 \%$. In Ukraine, people demonstrate a low level of trust in other state institutions as well. For instance, the judiciary is trusted by only $18.2 \%$, while the world average is equal to $52.6 \%$. Besides, only $20.5 \%$ of Ukrainians believe in the fairness of elections in Ukraine ${ }^{24}$.

The institutional environment for accumulating social capital is a system of social institutions, including state-and-legal, economic, sociocultural (science, education, art) and civil society institutions (professional associations, non-governmental organizations).

The relations in the system of social institutions develop both vertically (between the state and other public institutions) and horizontally (intersectoral interaction). Moreover, state-and-legal institutions and civil society institutions are two poles of the institutional environment and need to find a balance between them that is optimal for a particular society.

State-and-legal institutions affect all components of social capital, including all social institutions. Therefore, inefficient public admini-

\footnotetext{
${ }^{24} \mathrm{https}$ ://gtmarket.ru/ratings/legatum-prosperity-index.
} 
stration is a significant obstacle to social capital accumulation. In international comparison, Ukraine shows the worst results in terms of trust, the independence of the judiciary, the effectiveness of the legal system in resolving disputes, the reliability of law enforcement, bribery and favouritism in the decisions of officials. This state of state-and-legal institutions in Ukraine hinders the accumulation of social capital. Given the conditions of corruption and favouritism, the relations between personal and professional qualities of a person and their material wellbeing is minimized, i.e. the institutional environment does not contribute to the capitalization of human resources.

According to the latest World Values Survey, trade unions and religious organizations are the most numerous in Ukraine, while these organizations show the largest gap between formal and actual membership. Public organizations related to sports and recreation are ranked $3^{\text {rd }}$. The least numerous organizations are consumer unions, charities and environmental organizations (see Table 2).

Table 2

The Ukrainian population' involvement in the activities of non-governmental organizations

\begin{tabular}{|l|c|c|}
\hline \multirow{2}{*}{ Non-governmental organizations } & \multicolumn{2}{|c|}{$\begin{array}{c}\text { The share of the population involved } \\
\text { in NGOs (\%) }\end{array}$} \\
\cline { 2 - 3 } & total & actively \\
\hline Religious organizations & 11.9 & 4.3 \\
\hline Sports and recreational organizations & 7.4 & 3,7 \\
\hline Educational clubs & 4.4 & 1.6 \\
\hline Trade unions & 14.5 & 2,7 \\
\hline Political parties & 4.7 & 1.2 \\
\hline Environmental organizations & 1.4 & 0.3 \\
\hline Professional associations & 3.2 & 0.7 \\
\hline Charities & 2.8 & 0.8 \\
\hline Consumers unions & 2.0 & 0.8 \\
\hline
\end{tabular}

Thus, Ukrainian non-governmental organizations do not have the necessary influence on the socio-economic development of the state and regions. The activities of non-governmental organizations take place under difficult conditions of limited resources for their functioning. Many non-governmental organizations exist due to international grants. At the same time, their dependence on international grants creates counterproductive competition in terms of sources of funding. In this 
competition, large organizations have better chances of winning since they have relevant experience, well-established relationships with foreign donors and, thus, can overshadow local initiatives.

III. The result-related component. The result-related component of social capital accumulation reflects the end result from the realization of existing opportunities. Its importance, as well as the expediency of its isolation, is confirmed by the fact that its increase, in turn, contributes to developing other components (resource- and environment-related). Being the effect of quantitative and qualitative changes, the result-related component contains potential opportunities to reach a new level of functioning for both social capital and the system as a whole.

An integral indicator of the result-related component is the level of prosperity of the population. The Legatum Institute annually calculates the Prosperity Index, which covers most countries around the world. This index consists of eight sub-indices, such as economics, entrepreneurship and opportunities, public administration, education, healthcare, security, personal freedom, social capital. According to the Legatum Prosperity Index, Ukraine ranked $96^{\text {th }}$ in 2019 (54.50). The situation deteriorated significantly compared to 2014 when it ranked $63^{\text {th }}$ out of 142 countries and was included in the group of countries with an average level of the Prosperity Index. According to the components of the Legatum Prosperity Index in 2019, the positions of Ukraine among other countries are as follows: economics $-70^{\text {th }}$, entrepreneurship $-57^{\text {th }}$, public administration $-121^{\text {st }}$, education $-42^{\text {nd }}$, health $-77^{\text {th }}$, security $-54^{\text {th }}$, personal freedom $-103^{\text {rd }}$, social capital $-40^{\text {th }}$. Thus, one can see that the highest positions of Ukraine concern social capital and education and the lowest positions - public administration and personal freedom ${ }^{25}$.

\section{CONCLUSIONS}

Regarding the prospects of social capital institutionalization in Ukraine today, one can observe a low level of public activity and trust and, at the same time, a high level of alienation in Ukrainian society. In this aspect, one can talk about the existence of the so-called negative social capital, which is unlikely to contribute to social stability and security. Thus, it is essential to revive the traditions of self-organization and further intensify the creation of public activity networks which will ensure cooperation between people and promote a sense of trust and security. Otherwise, there is a threat of further polarization of society,

\footnotetext{
${ }^{25} \mathrm{https}: /$ gtmarket.ru/ratings/legatum-prosperity-index.
} 
intensification of confrontation between the rich and the poor and, eventually, slow development of civil society in Ukraine.

Therefore, further research should aim to disclose the issue of social capital in Ukraine and develop relevant methodologies to improve the functioning of the country's conscious civil society.

The analysis of social capital in Ukraine proves that its indicators of human capital are high and those of prosperity are low, which makes the environment-related component rather inefficient. The deficit of social capital acts as a significant obstacle to the implementation of the planned reforms. Besides, this analysis identifies positive and negative factors affecting its accumulation. The obtained results also have made it possible to measure the level of social capital in the system of social relations of Transcarpathian region. One can conclude that the level of social capital in the mentioned region is high.

\section{SUMMARY}

Thus, one can conclude that social capital can be accumulated during social interaction due to the expansion of social relations and the increasing range of useful acquaintances. In a certain accumulated state, these social relations create a network of established contacts which contribute to achieving the goals of some groups of people. Subsequently, many social networks integrate, become part of the social structure and affect the social life of the society. Therefore, further study of theoretical and practical principles of social capital is extremely important since it plays an important role in building strong social relations, which improves living standards in the country. The study of a person's axiological world and ways and patterns of its existence will help one to identify optimal forms of social relations, reconcile the interests of a particular person, different social groups, states, humanity and, most importantly, become a successful basis for social capital. Thus, social capital is a unique phenomenon determining positive interaction at the micro-, meso- and macro- levels, and social relations act as a resource to achieve goals. 


\section{REFERENCES}

1. Бек У. Общество риска: На пути к другому модерну. М.: Прогресс-Традиция, 2000. 383 с.

2. World Economic Forum. Global Risks 2013, Eighth Edition. URL: http://www.weforum.org/issues/global-risks.

3. Серый А. В., Яницкий М. С. Ценностно-смысловая сфера личности. Учебное пособие. Кемерово: Кемеровский государственный университет, 1999. С. 2-3.

4. Крупнов Ю. Борьба за личность. URL: http://www.kroupnov.ru.

5. Ritzer G. The McDonaldization of Society. An Investigation into the Changing Character of Contemporary Social Life. Thousand Oaks, CA: Sage, 1993.

6. URL: http://www.dridu.dp.ua/vidavnictvo/2017/2017_04(35)/11.pdf.

7. Фукуяма Ф. Конец истории и последний человек . М.: Ермак, 2004. $588 \mathrm{c}$.

8. Журавлев А.Л., Купрейченко А.Б. Нравственно-психологическая регуляция экономической активности. М., 2003. 436 с.

9. Скрипкина Т.П. Психология доверия. М., 2000. 264 с.

10. Почебут Л.Г. Психология социальных общностей. Толпа, социум, этнос. Изд-во СПбГУ, СПб., 2002. 176 с. URL: https://www.livelib.ru/author/238202-lyudmila-pochebu.

11. Шихирев П.Н. Природа социального капитала: соціальнопсихологический подход. Общественные науки и современность. 2003. № 2. C. 17-32.

12. Татарко А. Н. Индивидуальные ценности и социальнопсихологический капитал : кросскультурный анализ. Психология. Журн. Высш. шк. экономики. 2012. Т. 9, № 1. С. 71-88.

13. Багнюк А. Соціальний капітал і квантифікація суспільних процесів: тлумачення i функції. Мультиверсум. Філософський альманах: 3б. наук. пр. К., 2008. Вип. 71. С. 14-40.

14. URL: http://www.philosophy.univ.kiev.ua/uploads/editor/Files/ Vydanna/Visnyk.

15. URL: http://dspace.nbuv.gov.ua/bitstream/handle/123456789/ 38122/Chetverikova.pdf? sequence $=1$.

16. Социальный капитал личности: монография / Л. Г. Почебут, А. Свенцицкий, Л. В. Марарица, Т. В. Казанцева. М.: НИЦ ИНФРА-М, 2016. $250 \mathrm{c}$.

17. Е. Гугнін, В. Чепак Феномен соціального капіталу. Соціологія: теорія, методи, маркетинг. 2001. № I. С. 49-57. 
18. URL: https://zgbrand.ru/marketingovyeissledovaniya/cennostnyj_ oprosnik_sh_shva.

19. $\overline{\mathrm{UR}} \overline{\mathrm{L}}$ :

https://www.corteidh.or.cr/tablas/27917.pdf http://www.irbisnbuv.gov.ua/cgibin/irbis64r_81/cgiirbis_64.exe?C21CO $\mathrm{M}=2 \& I 21 \mathrm{DBN}=$ VFEIR\&P21DBN=VFEIR\&Z21ID=\&Image_file_name $=$ DOC $\% 2 F E I R 0021604 . P D F \& I M A G E \_F I L E \_D O W N L O A D=1$.

20. URL: https://zik.ua/blogs/buty_sered_pershykh_981037.

21. URL: https://mind.ua/news/20215947-indeks-lyudskogo-rozvitkuv-ukrayini-za-ostanni-10-rokiv-ne-pokrashchivsya.

22. URL: http://www.ukrstat.gov.ua/druk/publicat/kat_u/2018/zb/09/ zb_rlr2017_pdf.pd.

23. URL: https://gtmarket.ru/ratings/legatum-prosperity-index.

24. URL: https://gtmarket.ru/ratings/legatum-prosperity-index.

\section{Information about the author:} Smuk O. T.

$\mathrm{PhD}$ in Psychology, Associate Professor at the Department of Psychology, Uzhgorod National University 14, University str., Uzhhorod, 88000, Ukraine 